Témoigner Témoigner. Entre histoire et mémoire

Getuigen Revue pluridisciplinaire de la Fondation Auschwitz

$118 \mid 2014$

Au nom des victimes. Dictature et terreur d'État en Argentine, Chili et Uruguay

\title{
Memorial site: Downtown memorial
}

Site mémoriel : Downtown mémoriel

Herinneringsplek: Downtown memorial

Philippe Mesnard

Translator. Sarah Voke

\section{(2) OpenEdition}

Journals

Electronic version

URL: http://journals.openedition.org/temoigner/1281

DOI: 10.4000/temoigner.1281

ISSN: 2506-6390

Publisher:

Éditions du Centre d'études et de documentation Mémoire d'Auschwitz, Éditions Kimé

Printed version

Date of publication: 1 October 2014

Number of pages: 194-199

ISBN: 978-2-84174-674-3

ISSN: 2031-4183

Electronic reference

Philippe Mesnard, « Memorial site: Downtown memorial », Témoigner. Entre histoire et mémoire [Online], 118 | 2014, Online since 01 October 2015, connection on 23 October 2020. URL : http://

journals.openedition.org/temoigner/1281; DOI : https://doi.org/10.4000/temoigner.1281 


\section{Woordenboek over getuigenis en herinnering}
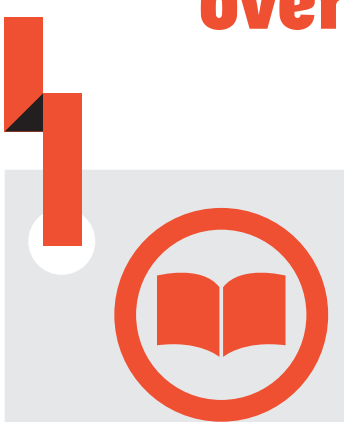

WORDS OF TESTIMONY AND OF MEMORY

$\diamond$ Because researchers,

working in the arts, culture or

news are more and more often

needing to use words from

memory Testimony between

history and memory has set itself

the objective of gathering them

into a dictionary, thus opening

up this experimental space.

One word can take on differen

meanings depending on the

in. This is why certain terms of

the dictionary will be approached

in a multilinguistic, or even in a

multicultural way.

$\diamond$ This project will be realized in two stages. Each term from an index in progress will be

presented twice. First in the form of short notices in each edition of the review, then inviting debate, with multiple voices, on from the Autumn 2014. We wil associate to their short version, voluntarly incomplete, a few book tilles, however not claimin

\section{CASSANDRA}

assandra, daughter of king Priam, briefly appears in the high walls of Troy, she shouts the high walls of Troy, she shouts to hor cor to express their grite after Hector tential is developed later, in the potatis tragedies. As a prophet inspired by Apschylus) and through the by (inceschlus) and through the goo use of her reason (in many modern inaudible knowledge. Though no thaudible knowledge. Though no the eradication of her city and the he eradication of her city and the to Mycena and the last worted to Mycenae and the last witness fall of Troy through the reverse fall of Troy through the reversa her tratic end (she is killed by her tragic end (she is killed by her position as a visiory her even to bear witness to a past that is not personal to her. in the tradition of $A$ schylus, in the tradition of Aeschylus, she recalis the crimes buried at the origin of the curse of the Atreids by Clytemestra and thema by Orestes ontra and the matricide by Orestes once again make new. of the future is in prediction the past, so of memory" (Romain

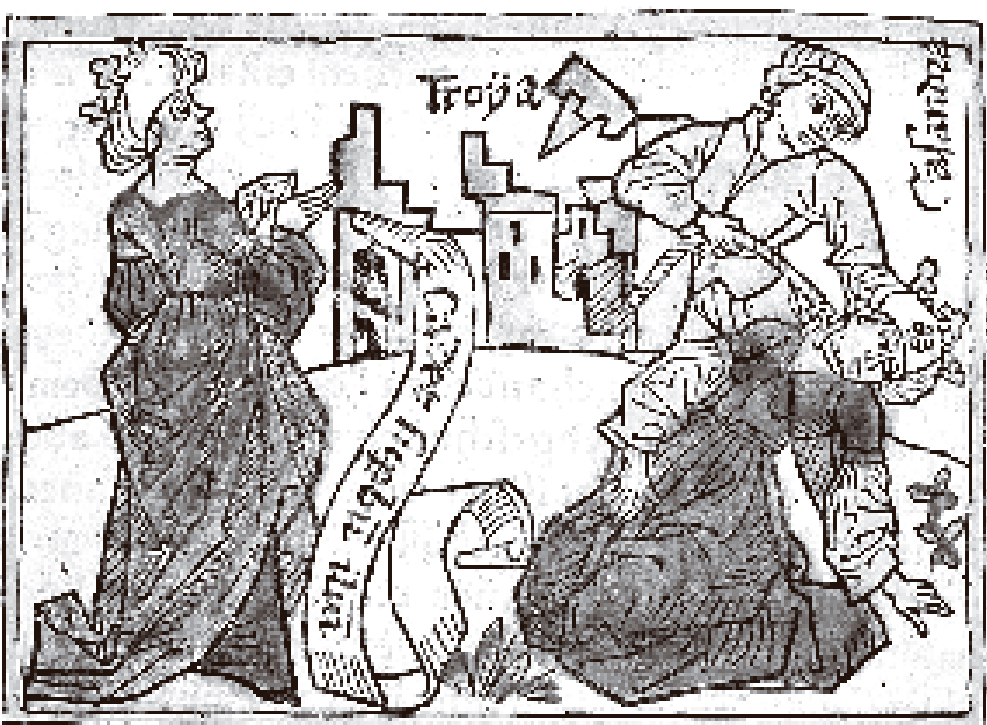
ords that resist being forgotten. From Aeschylus to Christa Wolf, she functions in the face of byicial History as a figure haunted ory larly in the light of the question artin the light of the question of "barbrian", measures "civilision" of the wine "civilsution" on Aeschylus, in the guise or a gift of hospitality, Cassandra asks the which no transmit her memory, the play or the trilog. "The Tro pet is dead . The word The Trojan the Greek poet", Giraudoux's prothe Greek poet , Giraudoux's protagonist declares in the final line Place. In the face of the et Take dition that is an of the epic trathe litery is an authority among the literary canon (the river of epic poems "), Wolf aims to make be heard in a nar or ("this be heard in a narrative ("this tiny from in thition from institutionalised genres, desecrates heroic values and of which Cassandra, having become an epoyynous heroine, is the nar-

The identity of this figure, her own mythological agenda, refers to some of the very properties of the ter in its own right. As an "inv- tive memory" (Marcel Detienne), a myth merely exists through its reception, offering a collective symbolizing tool particularly apt to bear witness to violences.

Véronique Léonard-Roques
University Blaise Pascal - CELIS EA 1002.
Clermont-Ferrand

$\Delta$ Goudot, Marie (ed.), Cassandre

Philippe Mesnard (eds.), Cassandre,

figure du témoignage et de transmiss

publication date: 2015

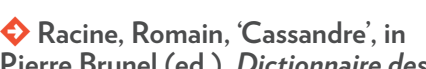

Pythes féminins, Monaco: Rocher.

2002.

Schérer, René, Zeus hospitalier. Coline 1993.

$\diamond$ Wolf, Christa, Cassandra, Trans.

Jan van Heurck. New York: Farrar,

Straus and Giroux, 1984 .
$\widehat{A}$ Léonard-Roques, Véronique \&

\section{THE GREY ZONE}

The multilinguistic and multiciultural approach second occurrence of "The grey zone", a Frediano Sessis paper on "La zone grise" in
Fon.

coin "grey zone" is a term coined by the Italian Holohis essay collection PrinoLevin and the Saved the last book he and the saved, the last book he "The Grey Zone", the secon chapter and the longest essay in chapter and the longest essay in human need to divide thes field into "us" and "the social clearly ditinct and identifia groups, but points int that such groups, but points out that such the face of the is inadequate in in the comps. "[T] he network in the canps. "Tl]he network of Lagers was nons simp, blcould not be reduced to the two blocs or victims and persecutors" after all, was to attempt to turn "it could not be reduced to thrites: victims into accomplices. Setting vich Lagers) the victims from the per"secutors" (25), insight into which ectors (25), busto which he considers to be of fundanental he by no means intends to oblitehe by no means intends to oblitetwo categories: "to confuse [the two categories: "to confuse [the moral disease or an aesthetic affecterion ity; above all, itis aprecions.

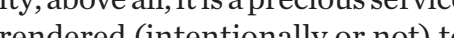
the negators of truth" (33).

The grey zone is inhabited mostly by victims who compromise and collaborate with thei oppressors to varying degrees an with varying degrees of freedom of choice in exchange for preferor che ensy judgne easy judgnent on these morally who found themselves flisoners, who foun themselves flung into who, moreover, did not contitute a monolithic group bonstiin a nich different with different levels of of or The low-ranking functionaries carrying out routine duties such carrying out hintine dicies such as bed Kapos of the lice checking, the racks chiefs the clerks, and those prisoners who performed diverse duties in the coms' administrative dutfices, the Political Section, the Labour Service, and the punishmabour Service, and the punishattention to the Sonderkommandos or "special squads", the groun cos or "special squads", the groups running of the entrusted with the one would hesitate to call privi en 
authorized to judge these individuals, who represent "[a]n extrem ment must also be suspended, art in the be suspended, he Chaim, in the perplexing case of Chain Rumkowski, the controil in the Lodz ghetto, anothe cil in the Lodz ghetto, another exene why occupant of the grey come length. While Levi prim focus on privileged Jewish p. couses on privileged Jewish pris-

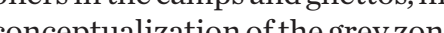
coptizin tretch to include collaborationFrance and Quising Fre andictic SS man who bu con a sadictic ss morin who briefly chen It is a reflection, ultis chamber. It is a reflection, ultinately, on the ambiguity of human nature in in many differe

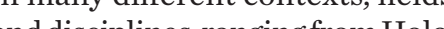
and disciplines, ranging from Holocast suw, fening a phe ogy, law, feminism, and popula

Stef Craps

\section{$\diamond$ Levi, Primo, 'The Grey Zone',
in Id., The Drowned and the Saved,}

\section{in Id., The Drowned and the Saved,
translated from the Italian by Raymon}

Rosenthal, London: Abacus, 1986/1989,

\section{MEMORIALIST}

he memorialist bears witness to his memory. It is expected of him that he fhares an exemplary experience plarity that his voice cy, an exemphe reprats the representation of the relation between the particularity of an erality of collective history. It usual condition of the memorialt's writing that he lived his own day in a remarkable way either as everise The ex, The exemplarity of his experihat ill workes into a narative thion The memorialist does not aroup. The me alone, but connected to his conthe traits of his generation dominant way or his generation and to the His ap embodied them himself. His approach to writing finds itsel and individuss between collective rind the solidatives, discovIn this polidarity between both. In this perspective, he could wish f his existence (family and senti(a) deeply per-

Ever since Memoirs have been considered as a writing form (in (r) bove he netzand the Duke of Cardinal de the two most well-kaint-Sinon, . rialists of the Ancien Regime. The (irst one participated in and gave account of his first-hand experience of the events of the Fronde; the second was a witness and mintoms of Louis XIV's court After the or Louis XIV's court. After well, the memorialist's testimu as well, the memorialist's testimony progressively gained freedom. It witness of histon by than as a public of history, by showing the public ss deeply personal, to write history Chateabriat writes the MemCirsthoun wites the Men-

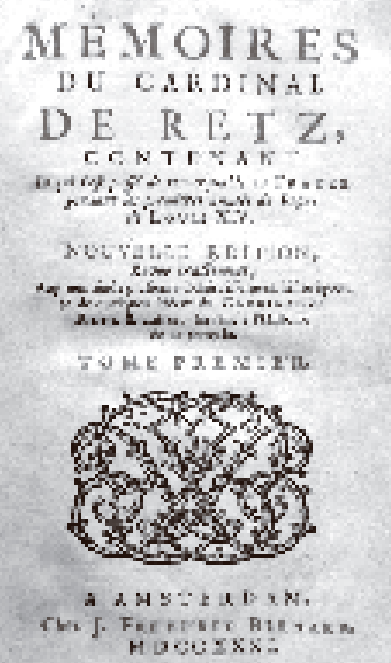

reference within French tradition Since then historical testimonies nolonger sition. History spelt with a capital H and reminding of "bat" (Perec) that it waved during (Perec) that it waved during the entire $20^{\text {h }}$ century, has finished sweeping the divisions we had fo the relations of the by shifting the relations of the individual to the group. Each memorialist show for which the ex anexperience for which the exemplary narrative

$$
\begin{array}{r}
\text { Damien Zanone } \\
\text { Université catholique de Louvain, } \\
\text { Louvain-la-Neuve }
\end{array}
$$

$\diamond$ Jeannelle, Jean-Louis, Écrire ses mémoires au XXe siectle. Déclin

$\diamond$ Jeanelle, Jean-Louis, Marc Hersant Damien Zanone (eds.), Le Sens du passé. Pour une nouvelle approche des et de littérature françaises de

$\diamond$ Zanone, Damien, Écrire son temps. yon: Presses universitaires de Lyon,
POSTMEMORY

'P een memory' beschrijft de bestand archief an verhaten atie van de 'volgende generatie' tot het per'bern die zij zich enkel kun-

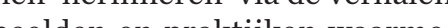
ze zijn opgegroid. De overevering van deze ervaringer veriep ech echter op zo'n intense en enoti(lijh alsof het werkelijk herinneringen zijn. en ert uit de hin vort uit de herinnering, maar is

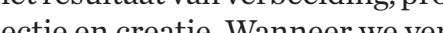
jectertere encerplettere heringen en opgroeien tussen verhalen die vor a coun an dat be dat ons eigen levensverhaal wor overschaduwd, of zelfs volledig verdrongen, door dat van onze veven, al is het oteknt dat ons werdt beh herst doochtstreeks, sordt beheerst door traunatisen die nog steeds elke neurtenissen die nog steds elke natieve constructie tarten en elk begrip ren mogen dan in het verleden liggen, zer mijn an naar mijn aanvoelen, de structuur de generatie

de generatie ervan kenmerkt.

Postmemory is geen basis om mar verwijst nar een claimen, maar verwjst naar een generatiodeverschillende manieren war die tot stand kanieren was die tot stand kan komen. Zelfs in haar meest intieme momenten is et gezinslever ver beelding bestaat uit imaginaire structuren en projecties eigen aan rchief aan verhalen e eelden, waardoor individuele e amiliale herinneringen veralgedeend en gedeeld kunnen worde traumatische ervaringen van de traumatische ervaringen van cie denovehalds de gebeurtenissen integreren ons eigen levensverhaal, zonder ze te imiteren of onrechtmatig to te eigenen?

Die vraag heeft niet allee etrekkingop het proces vanidentificatie, verbeelding en projectie dat (2) mar ook bij hen die als minde 作 ratie of relationeel netwerk ee (a) ook de nieuwsgierigheid, dedrang. effer

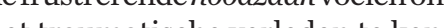
nen. Het gat hier echter om twe . cheid willen make tussen familiale en ' $g$ eaffitieede' postmemory warbij ik me baseer postnenory, waarbij ik mebaseer p het verschil tussen, enerzijds, en inn in een gezin, en anderzijds dentificatie onder tijdgenoten, die an voortvloeien uit de extrapolaie van het standpunt van dat kind tie vanhetstandpunt van dat kind. ondijgentio hebben met de tweede generatie. Het trauma wordt doorgegeve ia structuren die toegankelijk veed uicen tuigendgenog zijnonneengrotere in een orgin ringsoverdracht. we vaststellen bij hen die opgroe-
De 'post' in 'postmemory' Deer in dan alleen een ve traging in de tijd, meer dan ee in in de nasleep van de dinen. Ik wil me niet inschrijven i tïle logic, tenk die nog steeds een belangrijke pie nog steeds een belangrijke inter dernisme' 'posstructural on te tijkertijd tegelijkertijdeenkitische astand en een nauwe band met moderkismen structuralisme, "posteinde van het kolonialisme maar diens verontrustene mar ting terwijl 'postfeminisme' the, terwijl postfeminisme juist werd gebruikt om het vervolg op feen twiifel dat we ons nog theeds ( die-ten goede of ten lijiven tien ' 'postraumatis hatuen tieren: "posttraumatisch', risme' 'po maar ook 'postsecularisme', 'posthumanisme', 'postMorris , poptraciaal. Rosalind 'porris opperde onlangs dat de post wht zoals en Postit: het vlakte van teksten aan de oppervlakte van teksten en concepten, voegt er iets aan toe en transforridians 'supplement' Wel komde ideeën op de Post-its makkelik de ideeên op de Post-its makkelijk ie met hetboning Post-it afvalt moet het poss een Post-it afvalt, moet het postconhet in die precaire poan, en kan het in die precaire positie eige

'Postmemory' kent de gelaagd'poid en vertraging van de andere 'posts', en berust als praktijk op als de andere 'posts' zoekt 'postmemory' het onse zoekt 'postevenwicht op tussen continuïteit 
en ruptuur. Toch is postmemory geen beweging, methode of ide zan in van inter-en transgenerationele ter geer van traunatische kennis en belichaande ervaring. Het is eengevolg an traunatische herinn gen telling tot een postra matisch

Ik besef dat mijn omschrijvin van deze structuur van inter- en dransgenerationele trauna-overdracht evenveel vragen oproept houden wande Waron vasthouden aan de term herinnering', definier, on? be chering

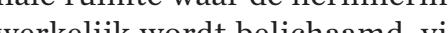
cke mo work belichaand, via die ruimte dan open kunnen we mer minder nauw verwante, adoptieve getuigen or geaffilieerde tijdgenoWaaro heces te betrekken? Waarom is postmemory eige Kunnen positieve geburen Kunnen positieve gebeurtenisse f ander ingisper onenter dan niet met eenzelfe anbivalente in we cit doorgegeven worden van de ene generatie op de andere? Welke esthetische en institutionele structuren, welke best de psychologie van pon het best de psychologie van postmemory weer, de continuiteit en discontinter tussen generaties, leemtes in de kennis, de angst en beklenming na het trauma? En en fotografie in het bijzol bijzondere rol zijn gaan spelen?

bijzondere rol zijn gaan spelen?
Marianne Hirsch

(Vertaling: Anneleen Spiessens)

\section{REDIGNIFICATION}

rom the Spanish neologism (redignificacion), redigniwhich the victions rime the victim of a violent che can overcome this condiattempt regining control of their own story. Used and theorsed wn story. Used and theorise Coloris by anthropologists, ociologists and by psychologists orking with victims of the most (1980-2000), redignification is on (1) cory undertak at locat and (t) ciations of victims and by public ciations of victins, and by public instances andinstitutions, namely The National Centre of Historica Memory (Centro Nacional de dememoriasistorica $w$ w.co)

In a context of generalised vioce, the vilus of fundanenthe par the resulting denial the person cause a feeling of lessness in the face of violenlesitimized by the of violences rmed actors. Memory is mest. arned actors. Memory is meant, cre, as a process allowing the a socialidentity as a response to social identity as a response to orsanizins organizations and institution f the conflict and aim to conory it into a means of redignif it into a means of redignification the from group and individu emert (expressing and sharing memort (ex), the vicim try to mens tins try to constructcoherent discourses that are supposed to allow thentron interpretation of the events.
The process of redignification is supposed to unfold in several steps. The narration of their memof the condition of victim of theconditionofvictim, as wella and the canding of the time span arom then, the recor the events. From then, the reconstruction of coherent naratives should allow a reinterpretation of past events because of the attribution of new itive feeling of indignation. from this feeling that victim from this feeling that victims are the shame and the guilt in which the acts and the guilt in which the acts and speeches of political criminals locked them. They should thus regain the control of their stories, of their lives, and recover a certain amount of selfindividuals, be able to claim their rights to co be to claim their rights to compensation for damable to decide their future. Finally, the public expression of minally, the public expression of memory should bring about the social and political recognition of the pain indly bring cloure to the proces ic redignification

$$
\begin{array}{r}
\text { Marie Ines Harté } \\
\text { Facultad de Finanzas, Gobierno }
\end{array}
$$

y Relaciones Internacionales - Universidad

(Translation: Sarah Voke)

$\diamond$ Bello, Martha Nubia, Identidad, dignidad y desplazamiento forzado. in Desplazamiento forzado intern en Colombia: Conflicto, Paz y desarrollo, Bogotá: ACNUR-

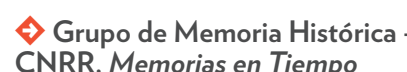
de Guerra. Repertorio de iniciativas Botogá, 2009.

$\diamond$ Villa, ljuan David, 'La memoria como territorio en disputa y fuente de velenta', in ICTJ, Recordaria conflicto: iniciativas no oficiales de
memoria en Colombia, Bogotá, 2009 .

\section{SOLDIER-POET}

n most countries at war in 1914 1918, a phenomenon quickly Depending on the country, its priters were the combattants (France and Belvium), Frontdichter (Germu soldier-poet (United Kingdom). These names refer to writers who, Ther havingexpenien to weave this ino litanaged to weave this into literary works and organized thenselves worn together an Association José This culturt

This cultural phenomenon developed due to the mobilization or voluntary engagement of intelers thus found thet. Many writers thus found themselves in the sine ftenfeltas paroxysm. The they published marked with thesed in ity. Even censored they responded ity. Even censored, they responded found in thationsor the forntin the rover "brainwan" supsorted to "brainwashing . Supported by criters ents and senri Ba busse, were quickly joined by younger were quickly joined by younger authors, solCenevoix or Ernst Jïner, and Genevoix or Ernst Junger, among the trenches.
Poetry, journal writing and wa practiced genres with didely practiced gen tes with differpres be because of literay traditions. War poetry was therefore more presKingdom than it was in France, Kingdom than it was in Trance, After the conflict, the forn of After the conflict, the form of the ily on the experiend more heavIndeed, if the publishing warend a notable revival at the turn of the 1920 s and 1930s with the publication of war movels gaining conidtion of war novels gaining consid1.2 million 1.2 inill Quiet on the Western Front (1929) book was translated into more tha fifty languages.

The texts of the soldier-poet their lively debates relating to debat Therrou lication of the first citical

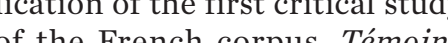
(1929), by Jean Nots (1929), by Jean Norton Cru, a lit former soldier. Accin an the tesold. According to him, texts toun preceden of these texts took precedence over al this light that he jug w only in this light that je jud wing ententy the authors Some of them namely Rolè retor, nam by stressing the literart disharply. of their work, which dimension red as just as fundamental a a testimony. undamental as CHEC Clermont-Ferrand UI (Translation: Sarah Voke) $\diamond$ Beaupré, Nicolass, Écrits de la guerr 2013.

$\rightarrow$ Campa, Laurence, Poètes de combattante et activité poétique, Paris Garnier, 2010

$\diamond$ Schoentjes, Pierre, Fictions de la

\section{THE RIGHTEOUS}

or more than ten years now, the "Righteous of France" honours from the State Conider toy as vernate term "Righteous" however th ther appeared recently within nationa

On 19 August 1953, in Israel, the members of the Knesset voted for the creation of the Yad Vashem Institute in order to preserve the memory of the martyrs and the an orisinally Talmudic expression, they entrusted it with the con, they entrusted "with the Among the Nations" "Ronteous who risked their lives to help Jews". Due to the materia difficulties the Yad Vashen met, this mission had Vashen met, this until the Fichman trial and the until the Eichmann trial and the cated to the Righteous in 1963 . Since then a commission pres. by a Supre court judge gides buling on the bourt judge gives a ruling on the basis of two testiconsidered to have beeple who The nominations were ocasions to present a medal ond accasions during an official cer a diploma Iuring an official ceremony led by

Until the mid-1980 few

Until the mid-1980s, few 


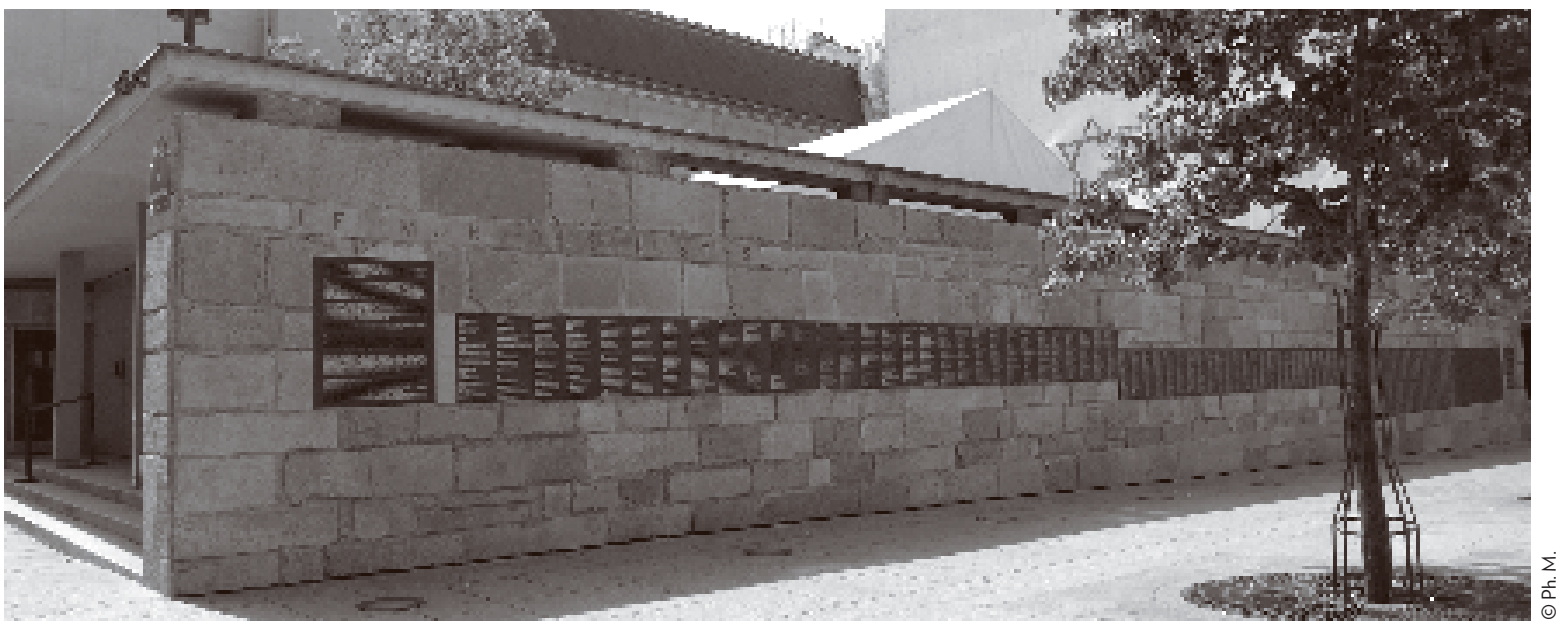
- Wall of the Righteouss, inaugurated
on 14 June 2006. Mémorial de la Shoa

Paris (2014)

Righteous. From 1985, however former Jewish Resistant fighter mobilized to make the title known Erance. On 1 January 2014 . During the inition During the initial period, cereDonies awarding medals were re and nost often organized in a conning an Israeliplace, they clly in townhalls and systentiextensive publicity. The nation extensive publicity. The national Assenbly celebrated for the first the saviours in 1995. During Jus thistorical speech dating from 16 Juy, the President of the Repub"Jich che ew national heroes.

This speech marked the begining of the progressive recovery (n) the Parliament thus proneuned t6 July as the "Day of conounced 6 July as the "Day of commemoration of racist and anti-Semitic State and of tribute to the f France". In January 2007, at

the request of the Foundation for the Remembrance of the Shoah, Jacques Chirac inaugurated plaque in the crypt of the Panon to signify the "Homage of the The rato the Righteous of France" The grand ceremony received ing the Israeli notion in witening the Israeli notion in order to who shall those who still are, and Who shall forever remain, anonymons croed in including those who "Righteur, of Frange" with "Rous of France" within

These new heroes serve

These new heroes serve th metorical it is a proven historical fact tha it is a proven historical fact that ent in France in 1940 did pot deportation. The few thoun nace Bighteons. The frim the Vasheous recognized by the Yad Vantl the majorty majorty within the French population. The second part of this reacoung the rations. It is certain the $\mathrm{f}$ the notion of disaster evokes apocalyptic literature as a genre and the tradition of Lamentations (Jeremiah), on the other pertain to the witing of disaster phich to the writing of disaster whe as stch, goes back to Maurice Blanchot. This witer particulary developeditin his eponymouscolThe Writing of the Distrer (1980) The Writing of the Disaster (1980) Step Not Beyond thus ater The step Not Beyond thus creating a sort of diptych. Emerging then at this point in the Eithin the intelits way into this category makes its way into testimonial texts on concentratio

isaster cannot be reduced to viewing events as a cataclysm of pistory, but to nake writing itseff itselfes such. More then anifests its survivors, disaster is the place of survivors, disaster is the place selves. A hostly languge that the inves. Aghostly language that has cor the the disaster is whe the as of hose who in winthout cose buried Testim without agrave are bured. because it is testimonial.
The notion of disaster is a articularly complex movement of thinking because as is ofte he case with Blanchot, concept old in paradoxes, or even i the notion of disaste tion thalles our representaat the same time what has already at the same tine what has already near Thus, there is neither a precise Thus, here is nether a precome dis nut the present che the that com the discer. Thu if "hack if it is still yet to come.

The writing of disaster stage a true poetic, that privileges th Lovi or the fragment, as Primo words of introdu to IfTh a Man. The form of the fras mits it escapes all descror bustingogy all sense of coming togeth it tells the of coming together,

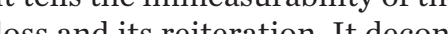
loss and the very pasibility deconnarrative. In this regity the work by Chate Delbo is partich significant Through her poetic an frasticant. Though herpoetic and the overwhelming change of language, wrought with horro (o muteness or to its confre, as anf ite stammer ng. To give every disappearance, every ash, a voice at the same time, ane be the task of the writing of disas-

It should be mentioned that philosephically, disaster, as in its proximity to the concept parity as express doy Levina in Otherwise Than Being Ber Essence in that dister is Essence, in that disaster is what escapes all forms of experience. ccording to the neolosen forged by Blanch to and wich forged by Blanchot, and wichrefers predety toastateoninertinnobity,

$$
\begin{array}{r}
\text { Éric Hoppenot } \\
\text { ESPE Paris IV La Sorbonne }
\end{array}
$$

(Translation: Sarah Voke)

$\diamond$ Celan, Paul, Choix de poèmes

translated from the German by

$\rightarrow$ Delbo, Charlotte, Aucun de nous Daris: Minuit, 1970. $\diamond$ Ertel, Rachel, Dans la langue de personne? Poesile yiddish de $\diamond$ Kofman, Sarah, Paroles suffoquées, Paris: Galilée, 1987. precedes history. I

$$
\begin{array}{r}
\text { Sarah Gensburger } \\
\text { CNRS/ISP }
\end{array}
$$

$$
\begin{array}{r}
C N R S / I S P \\
\text { (Université Paris Ouest Nanterre) }
\end{array}
$$

(Translation: Sarah Voke)

$\diamond$ Cabanel, Patrick, Histoire des Justes $\diamond$ Gensburger, Sarah, Les Justes de France. Politiques publiques de la 2010.

$\diamond$ Sémelin, Jacques, Persécutions Paris: Seuil, 2013. 
Memorial site

DOWNTOWN MEMORIAL

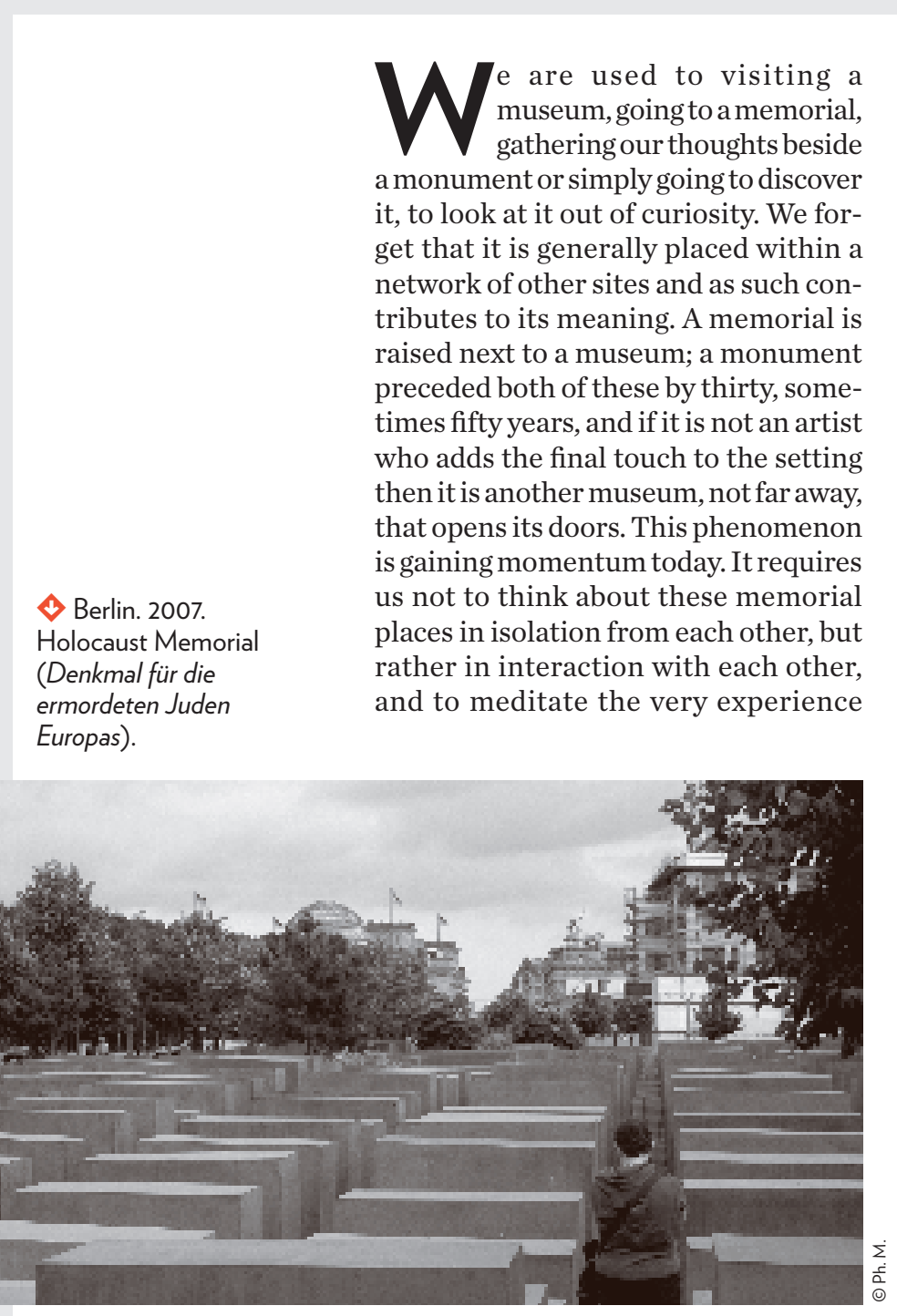

$\Leftrightarrow$ Berlin. 2008. Façade bearing the impact April 1945 shootings.

of the journey that leads us there. An ads us there. An experience where our footsteps carry us

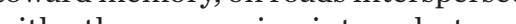

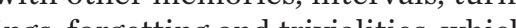
ings, forgetting and trivialities, whic Co Consider going down to the Memorial to the Murdered Jews of Europe a the hearts f the Noy crime and the history crning its memory after thstory conching tion (close to ifteen years of discussion the gen to restion of its location. In order to reach it, one must previously have physically crossed a complex layout of f history, levels and passageways full of history, memory, cultures, and also history and to the memory of the history and to the menory of a city that thact of the fights of (the corsdered Jews of Burope is set at the crossroads or several paths that come and go between Branderis style dating from the beginning of the ested aru of the Tirger, along the forested area of the Tiergarten, the dome
LEARN - Perec, Georges \& Robert MORE Bober, Récits d'Ellis Island,

histoires derrance et despoir [Ellis Island, stories of peregrinations and hope], INA 1979. A book was published Le Sorbier/INA.
- Prazan, Michaël, Angel lsland, lautre visage du rêve américain [Angel Island, the other face of the American Films du jour, 2014.
- Sturken, Marita, Tourist of History. Memory, Kitsch, and Consumerism from Oklahoma to Ground zero, Durhan University Press, 2007.

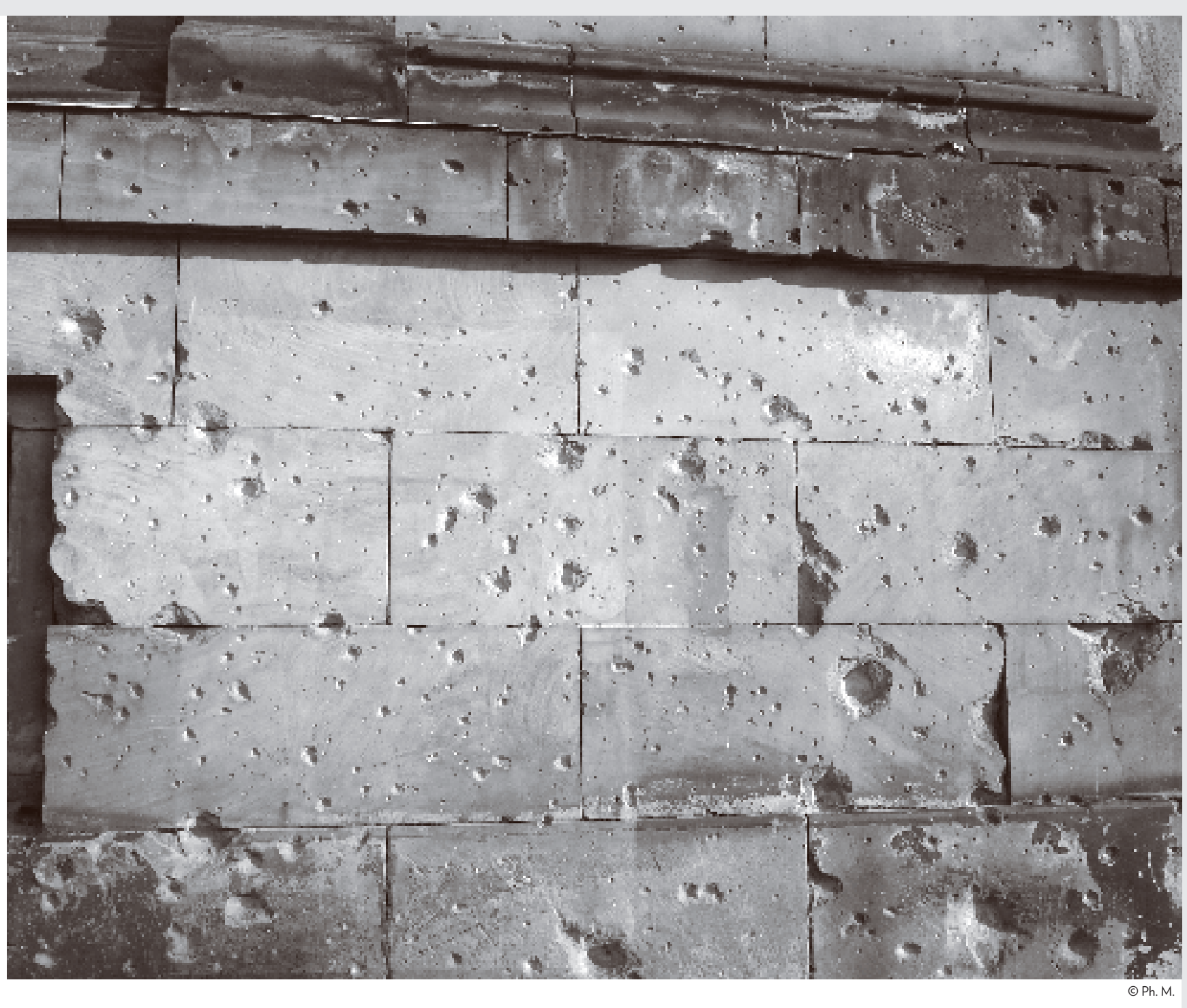


•. the long lines of curious people. On the other side, the Potsdamer Platz emerge like a mirage in the place of the forme the En wo separated tre has sprung up and vast shopping tre has sprung up and vast shopping imitating Time Squape beens

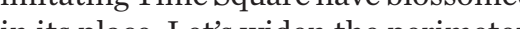
We thace. Let's widen the perimeter. Te then have the Topography or Terr the Jew (he the Bebelplatzwhere thehistorical Nazi book buning weremony took place and ow whe dibtion is situated (the 1995).

I had a similar feeling - this may seem paradoxical, or even odd as both

New York. 2014. 9/11 Memorial.

cities are so different - when I headed

Manhattan that has recently opened to what is called the "public", which I to what is called the "public", which stood muta mutandis, wither intention of comping whout any the to. For several mos ing these lines in Jun et - 1 am writhave to make our way there the will hume to make our way there through if we were still at the end of the 1990 at what becme not long aterwa the a Huse rare tic ineects which, perched on giganof mater some of which have ond of nater som recently been given a name in orde ory of the teror (the 9/11 Mun only to open mid-May) a d he pow

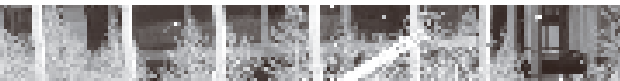

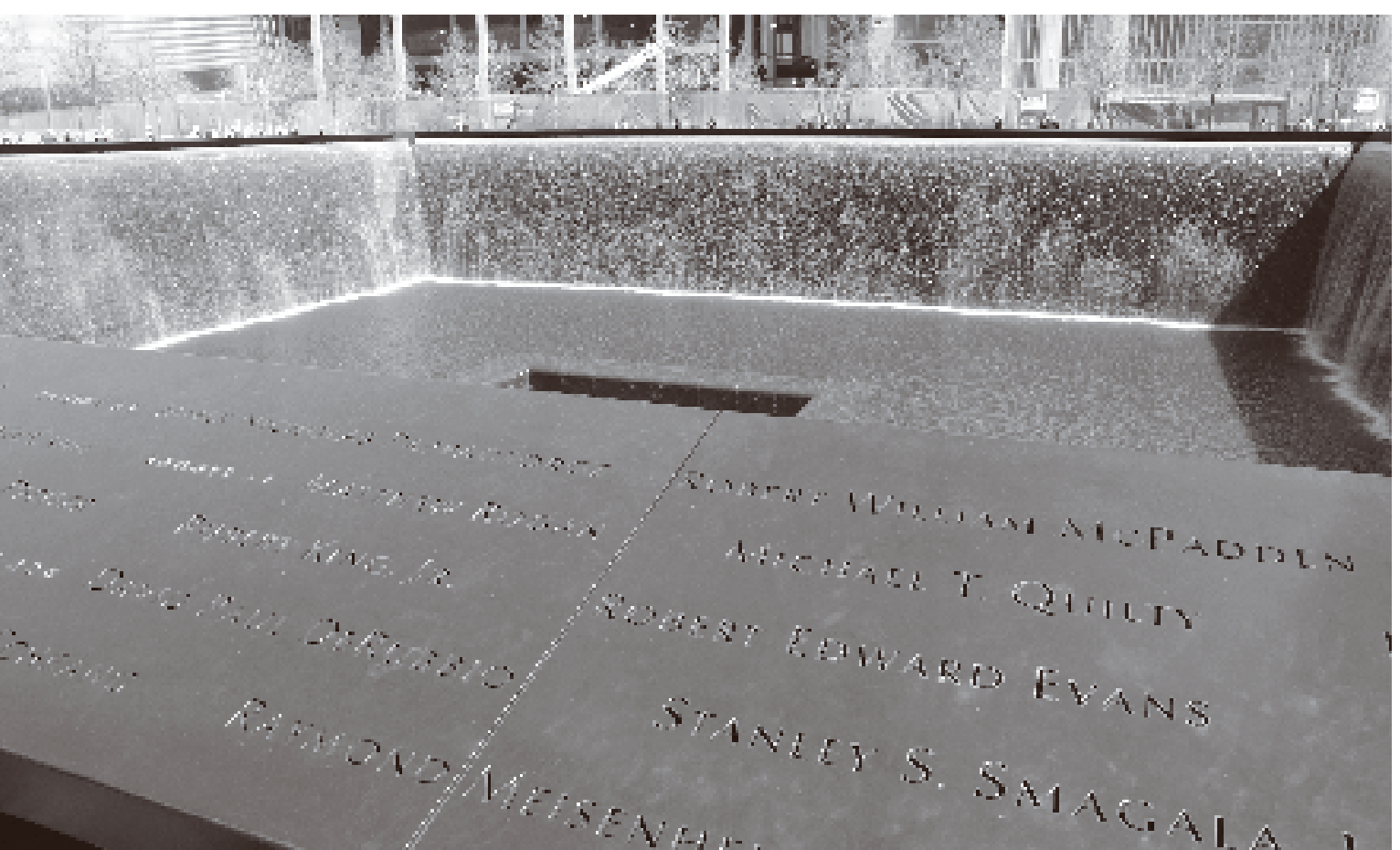

ofbusiness are already and forever near as the transcendence of capitalism conversely joins the impossibility - naturally transcendent - of measuring the wrong that was suffered.

And us, visitors, take a sinuous rout carefully overseen by security guards, policemen and guards making sure as much so that no one gets lost as that the order of our passage, person afte person, is carried out conscientiously whilst respecting a precise ritual. Each ficket is verifin and ticked, to be veriby one we pass theor four times. One by one we pass through a turnstile that dispensing the next toe hower dispensing the next guard from asking us - with the simplicity of American

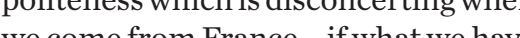
in the inner pocket of our jacket is fact our wallet and if on the jack cact our wallot and in on the there are in fact is trulyfulfiling is ex and thus participtes in the darfectly of the participates in the of the memorial. In addition to this troupe, we also find gurdes at the disposition of the public, who tell the story ere exanple of a tree that survived the ind inform the public fauttessly. We and inform the public faultlessly. We recognize a similar performance from that wereme at the Ellis Island Mut we is at this part of our heritage, served betwe part of our heritage, served between middle of the $20^{\text {th }}$ century as a place of midcle or the 20 to exam to the most nuthed of no entrance to the The Plaza of the Meno

The Paza of themorial is now open. Paradoxically, the effect is les

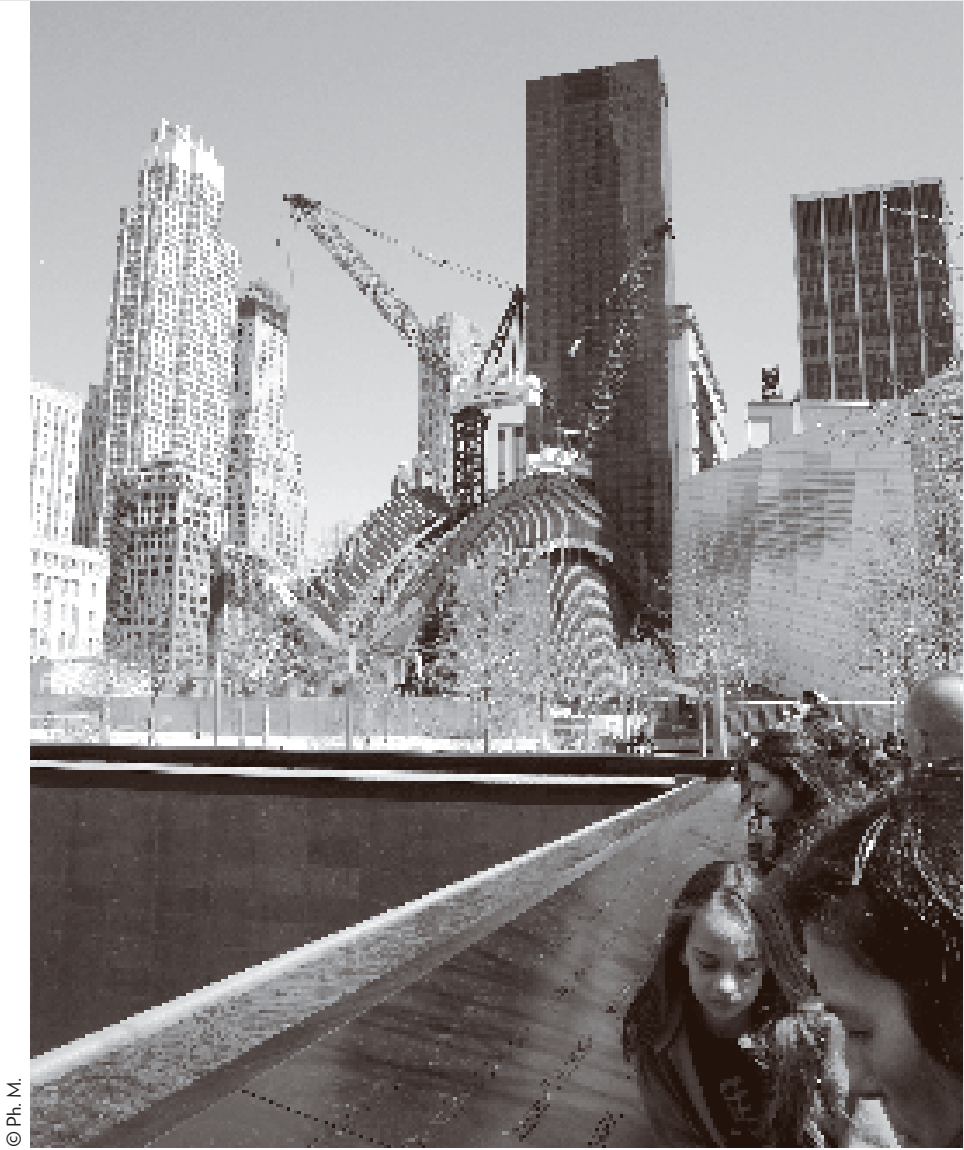

The Memorial's twin pools, each $\widehat{N}$ New York. 2014 $000 \mathrm{~m}^{2}$ in size and supposed to symbolize the base of both towers, would be more aesthetically striking if it were possible in situ to adopt the same point of view as the computer generated mages offered on the Internet. Thus the subtle position of the fountains, creating a reflecting absence effect, does produce he dizzying sensation that the virtual models prepare you for. The concept and its estimations remain above their oncrete realization, without exactly that there is for is also in this sense 


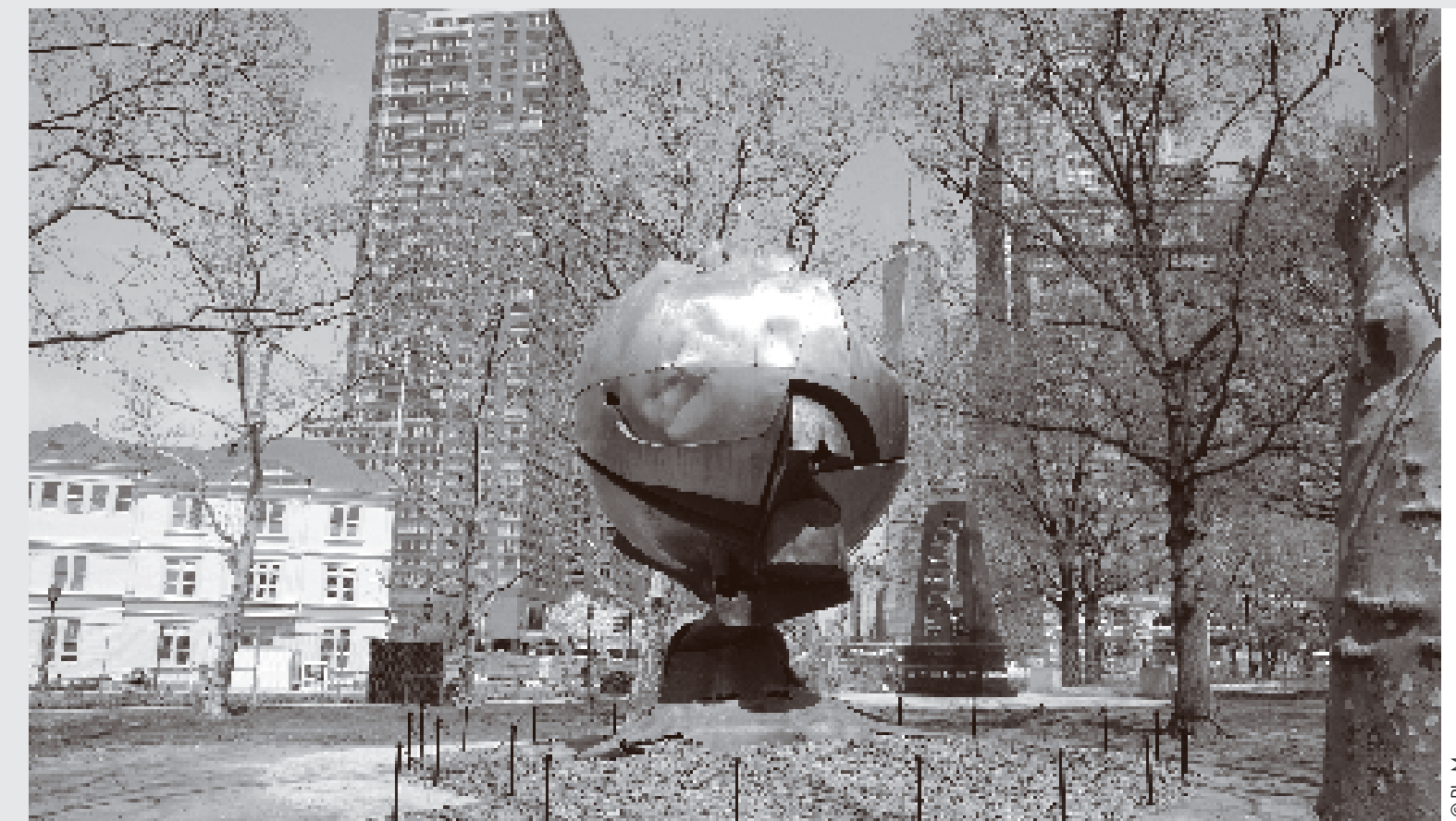

New York. Battery Park. 2014. In front, The (1971, originally Grofe Kugelkaryatide), relocated after the attack on the Twin Towers. Behind and on the right,
Mac Adams' Korean War Memorial (1991). In the background, the One World Trade Cente

that the idea cannot coincide with its reality. A gap that certainly responds to wanging to contro what took place by franingitwith In

In Berlin, the route between the of which are size, for ars equal in inclinntion or size, forbids the visitor from becoming a spectator and vion wiewng the whole memorial site. In the same way, here in Manhattan, the names of the three thousand victins the eight edges of the parapets surounding the pools aren't oppressive and naturally we cannot visually grasp the site in its entirety, even if we have the feeling that it is within reach. If there is a sense of grandeur, it is because the monument is continich illy uplifted by the visitors, bristle, a sense of ald that peubs to read the names of the deceased, to go toward the tree that survived, to feel the air se the that survived, to foel World Trade Cente. The new One indeed rises a cove every skysuctur New Yorkat 10 mers shaper mak the crou the quiet reflection of the crowd. In this way, the real monuthe spow the space much more than a perfectly configured sto humbly withdraw designed to humbly withdraw before the commenof the tension created by .

Let's make our way out of the $9 / 11$ Memorial and go back to the wider lefinition or the memorial ste as I outaned above. At the tip of Downtown, a triangle is delineated and covers in part, but upside down, the natural tri-
"Ground Zero" as we may have guessed, is the inside tip of the triangle. Before embarking for Ellis Island, you will have urchase a ticket for the Statue of Liberty and Ellis Island, the two other tip of this triangle which offer a different reading of the ground we tread upon. Nothing, obviously, in the minds of the organizers, justifies that we should only go to Ellis Island, since we are of course curious of the Statue (it is similar to th "unmissable" triangle Krakow, the salt mines of Wieliczka and... Auschwitz). As it is trivially said, one must "go al out" and see them all. This expression, though very unpleasant to the ears, perhaps not so stupid. In the minds of the agencies, ons be fully satisfied.

This memoy triangle acquires al This menory triangle acquires al its significance on the quay at Battery son. Waiting to bur for son. Waiting to embark for Liberty for at least an hour a patiently walked for at least an hour along the memoria to the Ans Second Wo war (eight he ing the Second World War (eight huge vecthour steles, four on each side, Koenig's famous sphere that after havin been serely damed after having been severely damaged during the the on these very banks, as well as Mac ma quite a few in a ratively small ches quite a few in a relatively shall space. And if we were to search further, Thus, with be more yet to discover. fhus, without even haing placed one Islond meat that will take us to Ells Island, no for of war and of terror saturate this few hus waters where queues of visitors stand waiting. Let's go directly to the island forming the last tip
of the triangle, Ellis Island.

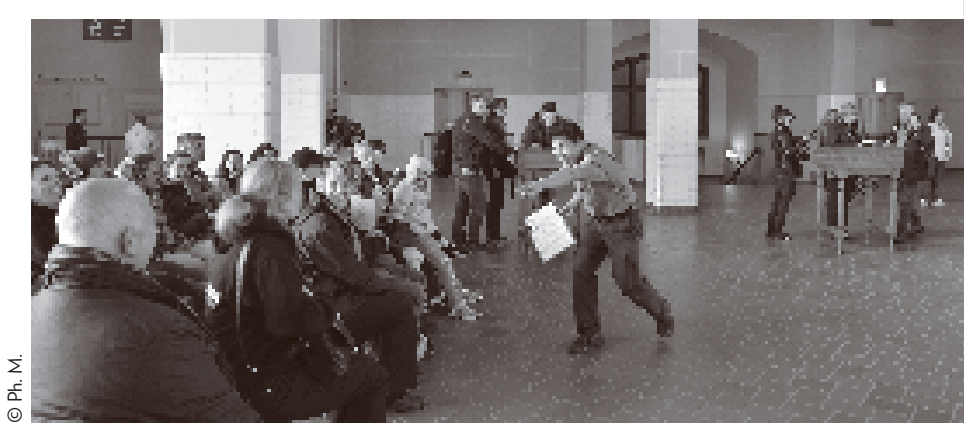

ث) Ellis Island. 2014.

Ellis Island has become a clean nd explanatory museum (which was not the case in Perec \& Bober's entirely remodiled, presting all of US history and the presenting all of brating it The at the same time, celeat times with a dra perform for free, enthus with a dramatic and solemn exagerated bute they would have held a the same role (I filmed have held a century earlier Quantities of photos, objects and facsuantities of photos, objects and facchiles dot thanage however to bring closer together the massive walls of the rooms where theinmigrants of the old Finally, chest have anything else to see beondoesn't tors (the pla tors (the placards and relics around the front of hin basically unnoticed), in the same family I suppose, sometim the same family I suppose, sometimes a few are staning trying to find one or or an archive docum or on archivedocuints that have been scanned. Here again, it is individuals visitors - that give the site its atman visitors - that give the site its atmosphere, a glimmer that the scenography Philippe Mesnard (Translation: Sarah Voke) 